九州大学学術情報リポジトリ

Kyushu University Institutional Repository

\title{
Cecidomyiid galls found on Jeju Island and in Sunchon and its vicinity, South Korea
}

Yukawa, Junichi

Entomological Laboratory, Faculty of Agriculture, Kyushu University

Uechi, Nami

National Institute of Fruit Tree Science

Ganaha, Tomoko

Okinawa Prefectural Agricultural Research Center, Itoman

Paik, Jong-Cheol

Department of Applied Biology, Sunchon National University

https://doi.org/10.5109/25395

出版情報 : ESAKIA. 52，pp.45-49，2012-03-27. Entomological Laboratory，Faculty of Agriculture， Kyushu University

バージョン：

権利関係: 


\title{
Cecidomyiid Galls found on Jeju Island and in Sunchon and its Vicinity, South Korea
}

\author{
Junichi Yukawa ${ }^{1)^{*}}$, Nami Uechi ${ }^{2)}$, Tomoko Ganaha-Kikumura ${ }^{3)}$ and Jong-Cheol PaIK ${ }^{4)}$ \\ 1) Entomological Laboratory, Faculty of Agriculture, Kyushu University, Fukuoka, 812- \\ 8581 Japan \\ 2) National Institute of Fruit Tree Science, Tsukuba, Ibaraki, 305-8601 Japan \\ 3) Okinawa Prefectural Agricultural Research Center, Itoman, Okinawa, 901-0336 Japan \\ 4) Department of Applied Biology, Sunchon National University, Jeonnam, 540-742 \\ Republic of Korea
}

\begin{abstract}
A total 25 sorts of cecidomyiid gall induced on at least 20 plant species across 12 families were found on Jeju Island in 2005 and in Sunchon and its vicinity in 2009. Among them, 13 sorts were new to Korea. These new findings have brought the total number of sorts of Korean cecidomyiid gall up to 67, of which $58(86.6 \%)$ are common to Japan. Figures for five sorts of gall that were not shown in the colored illustrated book (Yukawa \& Masuda, 1996) are provided in the present paper for future convenience in identifying galls and gall-inducing cecidomyiids.
\end{abstract}

Key words: Cecidomyiidae, distribution record, gall midge, Jeju Island, South Korea, Sunchon.

\section{Introduction}

Studying entomofauna of the Korean Peninsula is essential for understanding the origin of entomofauna of the Japanese archipelago because the peninsula connected the archipelago to Eurasia as a land bridge during glacial periods (e.g. Gohara, 1975; Minato, 1978). Therefore, a lot of information about entomofauna has been accumulated both in Korea (e.g. ESK \& KSAE, 1994) and in Japan (e.g., Hirashima et al., 1989). However, the knowledge of gall midge (Diptera: Cecidomyiidae) fauna of Korea is relatively insufficient. Until today, 53 sorts of cecidomyiid gall (52 in the number of species, because one polyphagous species was included) were recorded from Korea (Paik et al., 2004), which is much fewer than the 628 sorts found in Japan (Yukawa \& Masuda, 1996), although the area of Korea is about $220,000 \mathrm{~km}^{2}$, which corresponds to $58 \%$ of $378,000 \mathrm{~km}^{2}$ in Japan. Thus, we need to devote more time to search for gall-inducing cecidomyiids in Korea to examine similarities and dissimilarities of gall midge fauna between Japan and Korea.

After the study of Paik et al. (2004), JY, NU, TGK and
JCP visited Jeju Island in October 2005 in search of cecidomyiid galls, and JY and JCP surveyed gall-inducing cecidomyiids in Sunchon City and its vicinity in September 2009. Prior to the present paper, a new species, Rhopalomyia longicauda Sato et al. 2009 was described using some specimens collected from Jeju Island in 2005 (Sato et al., 2009). In addition, Pitydiplosis puerariae Yukawa et al. 2012 was recently described using specimens collected from Sunchon and Damyang in 2009 (Yukawa et al., 2012). In this paper, we enumerate all these gall midges that we found in South Korea after Paik et al. (2004) for future comparative faunistic study of gall midges between Japan and Korea.

\section{Materials and Methods}

In October 2005, we visited Jeju Island, which is about $1,845 \mathrm{~km}^{2}$ in area and situated in the East China Sea about $80 \mathrm{~km}$ south of the southwestern tip of the Korean Peninsula, and spent two and half days on the island for field survey. The sites we surveyed were as follows: Gwaneumsa Temple (N3325'23", E1263'33", Alt.

E-mail: JZS02305@nifty.ne.jp 


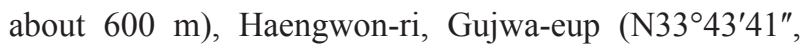
E126 $43^{\prime} 48^{\prime \prime}$, Alt. about $2 \mathrm{~m}$ ), near Jeju National University (N3345'82", E126 56'08", Alt. about 700 m), Jeju Sinchang coast road (N33 ${ }^{\circ} 19^{\prime} 43^{\prime \prime}$, E126 09'48", Alt. about $0 \mathrm{~m}$ ), near Jeju YMCA Camp site (N33⒉6'00", E126 29'21", Alt. about 400 m), Jeolmul Natural Forest Resort (N3318'39", E12627'23", Alt. about 700 m), Jungmun Beach (N33 $14^{\prime} 40^{\prime \prime}$, E1262 $4^{\prime} 55^{\prime \prime}$, Alt. about 20

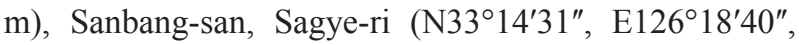
Alt. about $28 \mathrm{~m}$ ), near Seong-san Ilchulbong Peak (N33 ${ }^{\circ} 7^{\prime} 49^{\prime \prime}$, E126 56'16", Alt. about $\left.16 \mathrm{~m}\right)$ and

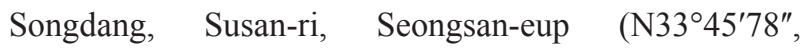
E126 $77^{\prime} 05^{\prime \prime}$, Alt. about $70 \mathrm{~m}$ ).

From 22 to 24 September 2009, JY and JCP surveyed cecidomyiid galls in Sunchon City and its vicinity, South Korea, such as Sunchon Bay Wetland Nature Reserve (N34 $\left.53^{\prime} 01^{\prime \prime}, \quad E 127^{\circ} 30^{\prime} 77^{\prime \prime}\right)$, Sunchon Minsokchon

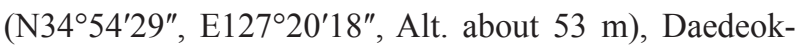

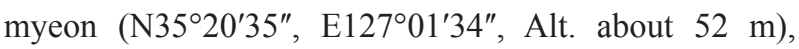

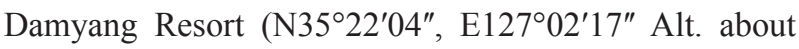

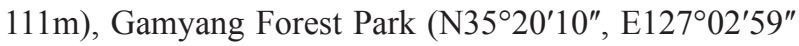
Alt. about 135m) and Sunamsa (N34'59'44", E127 19'52", Alt. about $232 \mathrm{~m}$ ).

We identified gall midges based on their morphological features, host plant information and the shape of galls. Particularly because many gall-inducing cecidomyiids are mono- or oligophagous and the appearance and structure of cecidomyiid galls are generally specific to each gall midge species (e.g. Gagné, 1989; Yukawa and Masuda, 1996), we compared the galls found in Korea with allied Japanese cecidomyiid galls illustrated in Yukawa \& Masuda (1996).

\section{Result and Discussion}

A total 25 sorts of cecidomyiid gall induced on at least 20 plant species across 12 families were found on Jeju Island and in Sunchon and its vicinity, South Korea (Table 1). Thirteen sorts out of the 25 were new to Korea, of which two sorts, leaf galls on Celtis sp. (Cannabaceae) and flower bud galls on Lespedeza cuneata (Dumont) G. Don (Fabaceae), have never been found in Japan. The finding of the 13 new sorts has brought the total number of sorts of Korean cecidomyiid gall up to 67, counting 53 in Paik et al. (2004) and the one sort induced on Chrysanthemum indicum Linnaeus (Asteraceae) by Rhopalomyia longicauda Sato, Ganaha \& Yukawa, 2009 that was recorded from Jeju Island and China (Sato et al., 2009). The 67 sorts of gall are induced on at least 46 plant species belonging to 21 plant families. Host plant species are mostly common to Japan.
Among 53 sorts of cecidomyiid gall enumerated in Paik et al. (2004), 47 (88.7 \%) were common to Japan. The current data including $R$. longicauda indicated that the 11 sorts $(84.6 \%)$ out of 14 were common to Japan. Combining these data, $58(86.6 \%)$ out of 67 sorts were common to Japan. The number of sorts, 67 , is still much fewer than 628 in Japan (Yukawa \& Masuda, 1996). However, as predicted by Paik et al. (2004), an increase in the number of sorts of gall from 53 in 2004 to 67 in 2009 means that further cecidomyiid galls will be found in Korea by additional field surveys of plant species that are known as host plants in Japan.

Figures 1 to 5 show cecidomyiid galls that were not given in the colored illustrated book by Yukawa \& Masuda (1996). The figures may be useful for identification of galls and gall-inducing cecidomyiids in future studies. Fruit galls induced by Asphondylia sp. on Phytolacca americana Linnaeus (Phytolaccaceae) is not shown in this paper because Uechi et al. give a photograph of the galls in a separate paper in this volume of Esakia. Long conical leaf galls induced on Celtis sp. by Celticecis sp. (Fig. 1) is taller and more slender than the conical leaf galls on Celtis sinensis Persoon (Cannabaceae) by Celticesis japonica Yukawa \& Tsuda, 1987 (Yukawa \& Tsuda, 1987; C-202 in Yukawa \& Masuda, 1996). Obolodiplosis robiniae (Haldemann, 1847) that induces leaf margin roll gall on Robinia pseudoacacia Linnaeus (Fabaceae) (Fig. 2) is a North American species recorded from Japan and South Korea (Kodoi et al., 2003). Rhopalomyia longicauda induces large subglobular swellings on the terminal and lateral buds of $C$. indicum (Fig. 3) on Jeju Island. This species is also distributed in China (Beijing and Hebei, Henan, Shandong, Anhui, Zhejiang, Hubei, and Hunan Provinces) but not in Japan (Sato et al., 2009). Two unidentified gall midges induce flower bud galls on $L$. cuneata (Fig. 4) and Rubia argyi (H. Léveillé \& Vaniot) H. Hara ex Lauener (Fig. 5), which have never been found in Japan.

In addition to the aforementioned gall-inducing cecidomyiids, Yukawa et al. (2011) regarded an unidentified gall midge that had been recorded as a pest of Pyrus pyrifolia (Burman, F.) (Rosaceae) from Gyeongsan Nam Do, South Korea (Aoyama, 1938) to be identical with Resseliella yagoi Yukawa \& Sato, 2009. However, this species was excluded from the current data of gall-inducing cecidomyiids because its larvae live in the core of fruit or under the bark of $P$. pyrifolia without gall induction.

\section{Acknowledgements}

We wish to thank Dr. Sai-Ho Jung (Chief of Zoology 


\section{CECIDOMYIID GALLS FOUND IN SOUTH KOREA}

Department, Jeju-Do Folklore \& Natural History Museum, Jeju City) and Messrs. T. Higuchi, K. Mitai, R. Murao, H. Yoshitake and Ms C. Okamoto (students from Entomological Laboratory, Kyushu University at that time) for their help in the field survey on Jeju Island. We are grateful to Dr. L. J. Westover (Entomological Laboratory, Kyushu University) for his kindness in brushing up an early draft and Dr. Y.-C. Jung (Department of Biology, Sunchon National University) for identifying plant species in South Korea. Our thanks are also due to Prof. O. Tadauchi, Dr. S. Kamitani and Mr. D. Yamaguchi (Entomological Laboratory, Kyushu University) for their support.

Table. 1. A list of gall-inducing cecidomyiids found on Jeju Island in 2005 and in Suncheon City and its vicinity in 2009.

\begin{tabular}{|c|c|c|c|c|}
\hline Gall midge & Host plant in Korea & Gall \& Figure ${ }^{1)}$ & Locality & Record $^{2)}$ \\
\hline Asphondylia sphaera & Oleaceae: Ligustrum japonicum & Fr (D-027) & Naganeupseong Folk Village, Sunchon & NK \\
\hline Asphondylia sp. & $\begin{array}{l}\text { Phytolaccaceae: Phytolacca } \\
\text { americana }\end{array}$ & $\mathrm{Fr}^{4)}$ & Songdang, Susan-ri, Bonggae-dong, Jeju & NK \\
\hline Celticesis sp. & Cannabaceae: Celtis sp. & Lf (Fig. 1) & Seonamsa, Sunchon & NK \\
\hline Lasioptera achyranthii & $\begin{array}{l}\text { Amaranthaceae: Achyrantes } \\
\text { bidentata, }\end{array}$ & St (C-245) & $\begin{array}{l}\text { Jeolmul Natural Forest Resort, Bonggae-dong, Jeju; } \\
\text { Seonamsa, Sunchon }\end{array}$ & 5 \\
\hline Daphnephila machilicola & Lauraceae: Machilus thunbergii & $\operatorname{Lf}(\mathrm{C}-256)$ & Jungmun Beach, Seogwipo, Jeju & 5 \\
\hline Lasioptera euphobiae & $\begin{array}{l}\text { Asteraceae: Eupatrium } \\
\text { lindleyanum }\end{array}$ & St (D-092) & Gamyang Forest Park, Damyang & NK \\
\hline Lasioptera paederiae & Rubiaceae: Paederia foetida & $\mathrm{Vn}$ & Gamyang Forest Park, Damyang & 2,5 \\
\hline Masakimyia pustulae & Celastraceae: Euonymus japonicus & $\operatorname{Lf}(\mathrm{C}-381)$ & near Jeju National Univ., Ara 1-dong, Jeju & 5 \\
\hline Obolodiplosis robiniae & Fabaceae: Robinia pseudoacacia & Lf (Fig. 2) & Jeju Sinchang coast road, Yongsu-ri, Jeju & 3,5 \\
\hline Pitydiplosis puerariae & Fabaceae: Pueraria lobata & $\operatorname{Lf}(\mathrm{C}-339)$ & $\begin{array}{l}\text { Suncheon Bay Wetland Nature Reserve, Sunchon; } \\
\text { Damyang Resort, Damyang }\end{array}$ & $1,6,9$ \\
\hline $\begin{array}{l}\text { Pseudasphondylia } \\
\text { rokuharaensis }\end{array}$ & $\begin{array}{l}\text { Caprifoliaceae: Viburnum } \\
\text { dilatatum }\end{array}$ & $\operatorname{Fr}(D-059)$ & Gwaneumsa Temple, Ara 1-dong, Jeju & NK \\
\hline Rabdophaga salicivora ${ }^{3)}$ & Salicaceae: Salix spp. & Tw $(\mathrm{C}-021)$ & Suncheon Bay Wetland Nature Reserve, Sunchon & $1,2,5,7$ \\
\hline Rhopalomyia cinerarius & Asteraceae: Artemisia princeps & $\operatorname{Lf}(\mathrm{D}-113)$ & $\begin{array}{l}\text { near Jeju National Univ., Ara 1-dong, Jeju; } \\
\text { Songdang, Susan-ri, Bonggae-dong, Jeju; } \\
\text { near Jeolmul Natural Forest Resort, Jeju }\end{array}$ & NK \\
\hline Rhopalomyia longicauda & $\begin{array}{l}\text { Asteraceae: Chrysanthemum } \\
\text { indicum }\end{array}$ & Bd, Lf (Fig 3) & $\begin{array}{l}\text { near Seong-san Ilchulbong Peak, Seongsan-ri, Jeju; } \\
\text { Sanbang-san, Sagye-ri, Jeju }\end{array}$ & 8 \\
\hline Rhopalomyia longitubifex & Asteraceae: Artemisia princeps & $\mathrm{Ab}(\mathrm{D}-109)$ & Jeonnam, Sunchon & 4,6 \\
\hline Rhopalomyia struma & Asteraceae: Artemisia princeps & St (D-102) & $\begin{array}{l}\text { Gwaneumsa Temple, Ara 1-dong, Jeju; } \\
\text { Haengwon-ri, Gujwa-eup, Jeju; } \\
\text { Damyang Resort, Damyang }\end{array}$ & $1,2,4,5$ \\
\hline Rhopalomyia yomogicola & Asteraceae: Artemisia princeps & $\operatorname{Lf}(\mathrm{D}-112)$ & Damyang Resort, Damyang & $1,2,4,5$ \\
\hline Rhopalomyia sp. & $\begin{array}{l}\text { Asteraceae: Chrysanthemum } \\
\text { indicum }\end{array}$ & $\mathrm{Bd}(\mathrm{D}-087)$ & $\begin{array}{l}\text { Sanbang-san, Sagye-ri, Jeju; } \\
\text { Jungmun Beach, Seogwipo, Jeju }\end{array}$ & NK \\
\hline Gen. sp. & $\begin{array}{l}\text { Amaranthaceae: Achyranthes } \\
\text { bidentata }\end{array}$ & $\operatorname{Fr}(\mathrm{C}-246)$ & near Jeju YMCA Campsite, Nohyeong-dong, Jeju & NK \\
\hline Gen. sp. & Asteraceae: Solidago sp. & Fl (D-071) & Gwaneumsa Temple, Ara 1-dong, Jeju & NK \\
\hline Gen. sp. & Fabaceae: Lepedeza cuneata & $\mathrm{Fb}$ (Fig. 4) & near Jeju YMCA Campsite, Nohyeong-dong, Jeju & NK \\
\hline Gen. sp. & Fabaceae: Pueraria lobata & $\operatorname{Lf}(\mathrm{C}-338)$ & Suncheon Bay Wetland Nature Reserve, Sunchon & NK \\
\hline Gen. sp. & Lauraceae: Machilus thunbergi & $\operatorname{Lf}(\mathrm{C}-262)$ & Songdang, Susan-ri, Seongsan-eup, Jeju & NK \\
\hline Gen. sp. & Rubiaceae: Rubia argyi & Fb (Fig. 5) & Jungmun Beach, Saekdal-dong, Jeju & NK \\
\hline Gen. sp. & Vitaceae: Vitis sp. & Lf (C-394) & Seonamsa, Sunchon & 1,5 \\
\hline
\end{tabular}

1) Galled portion. Ab: axillary bud, Bd: leaf bud, Fb: flower bud, Fl: flower, Fr: fruit, Lf: leaf, St: stem, Tg: twig, Vn: vein. Letter and numeral in parentheses indicate the photograph number of an allied gall recorded from Japan by Yukawa and Masuda (1996).

2) References of collecting record. 1: Saitô (1932), 2: ESK \& KSAE (1994), 3: Kodoi et al. (2003), 4: Ganaha et al. (2004), 5: Paik et al. (2004), 6: Ganaha et al. (2007), 7: Sato \& Yukawa (2006); 8: Sato et al. (2009), 9: Yukawa et al. (2011), NK: New to the Korean Peninsula (the current data).

3) Rabdophaga salicivora was recorded as R. rigidae in Paik et al. (2004) based on Nijveldt and Yukawa (1982) but resurrected by Sato and Yukawa (2006).

4) See Uechi et al. in this volume of Esakia for the photograph of fruit galls on Phytolacca sp. 


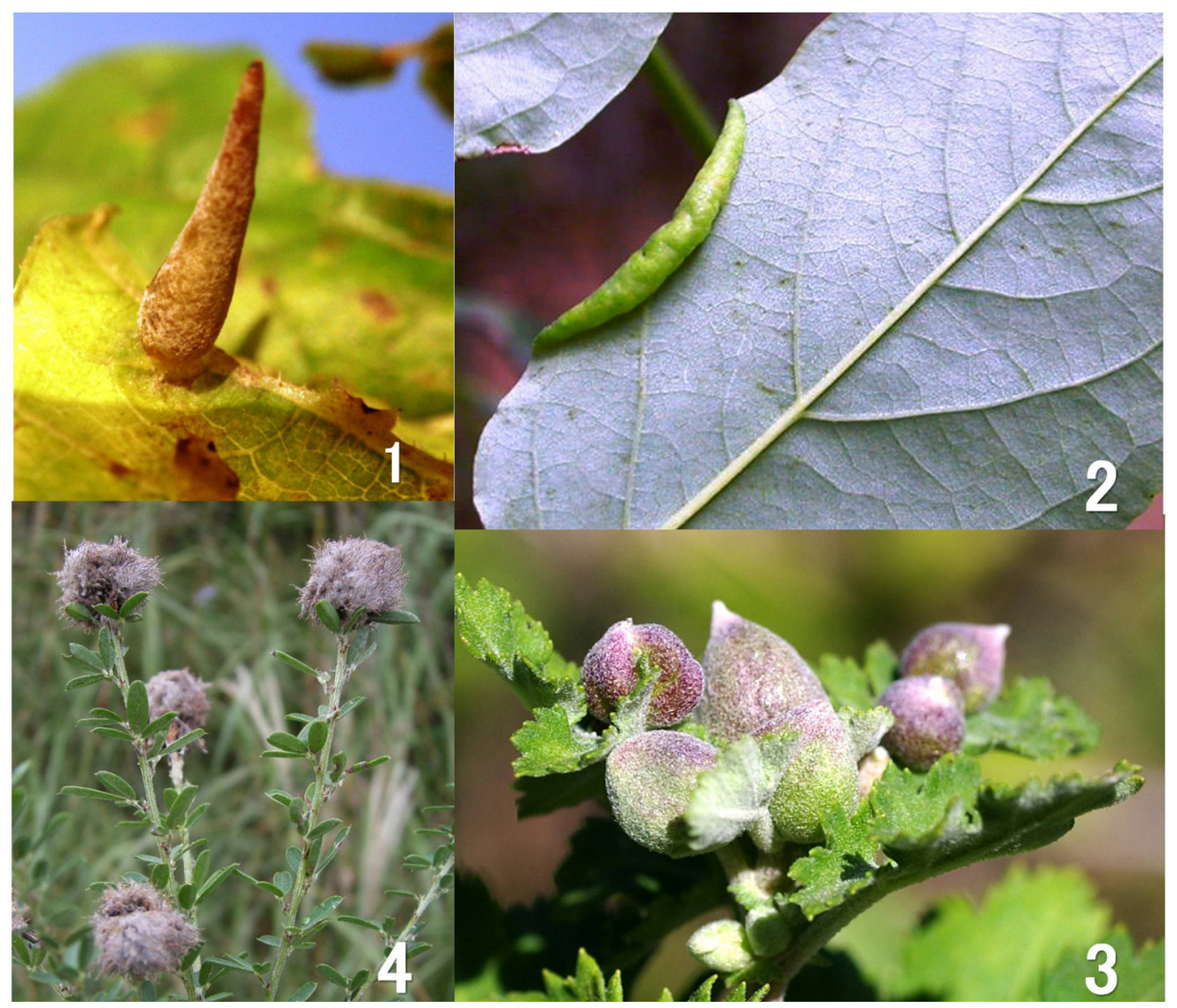

Figs. 1-4. Photographs of the Korean cecidomyiid galls found after 2004. 1. Slender conical leaf gall induced on Celtis sp. by Celticecis sp.; 2. Leaf margin roll gall induced on Robinia pseudoacacia by Obolodiplosis robiniae; $\mathbf{3}$. Terminal bud galls induced on Chrysanthemum indicum by Rhopalomyia longicauda: 4. Flower bud galls induced on Lepedeza cuneata by an unidentified gall midge.

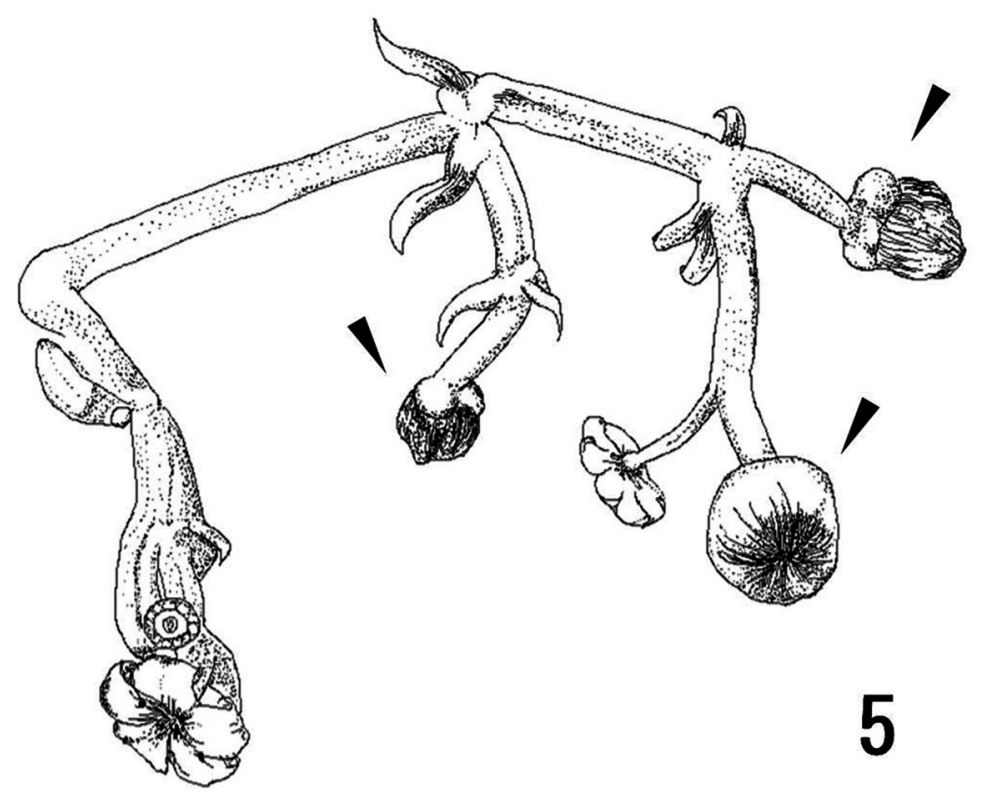

Fig. 5. Flower bud galls induced on Rubia argyi by an unidentified gall midge. Arrows point toward flower bud galls. 


\section{CECIDOMYIID GALLS FOUND IN SOUTH KOREA}

\section{References}

Aoyama, T., 1938. Pear codlin midge Diplosis n. sp. Nippon Gakujutsu Kyôkai Hôkoku, 13: 473-476.

ESK \& KSAE (The Entomological Society of Korea \& The Korean Society of Applied Entomology), 1994. Check list of insects from Korea. 744 pp., Kon-Kuk University Press, Seoul.

Gagné, R. J., 1989. The Plant-Feeding Gall Midges of North America. 356 pp., Cornell University Press, Ithaca.

Ganaha, T., J. Yukawa, N. Uechi, M. Nohara \& J.-C. Paik, 2004. Identifications of Some Species of the Genus Rhopalomyia (Diptera: Cecidomyiidae) Inducing Galls on Artemisia (Asteraceae) in Korea. Esakia, (44): 45-55.

Ganaha, T., M. Nohara, S. Sato, N. Uechi, K. Yamagishi, S. Yamauchi \& J. Yukawa, 2007. Polymorphism of axillary bud galls induced by Rhopalomyia longitubifex (Diptera: Cecidomyiidae) on Artemisia princeps and A. montana (Asteraceae) in Japan and Korea, with the designation of new synonyms. Entomol. Sci., 10: 157-169.

Gohara, Y., 1975. The Japanese archipelago during the glacial period. Urban Kubota, 11: 4-11.

Hirashima, Y. (supervisor), Entomological Laboratory, Faculty of Agriculture, Kyushu University \& Japan Wild Life Research Center (eds.), 1989. A Check List of Japanese Insects. 1,767 pp., Fukuoka. (In Japanese.)

Kodoi, F., H.-S. Lee, N. Uechi \& J. Yukawa, 2003. Occurrence of Obolodiplosis robiniae (Diptera: Cecidomyiidae) in Japan and South Korea. Esakia, (43): 35-42.

Minato, M. (editorial supervisor), 1978. The history of the Japanese archipelago, illustrated book of ancient geography. 133 pp., Tsukiji Shokan, Tokyo.

Nijveldt, W. C. \& J. Yukawa, 1982. A taxonomic study on Salixinhabiting gall midges in Japan (Diptera, Cecidomyiidae). Bull. Kitakyushu Mus. Nat. Hist., 4: 23-56.

Paik, J-C., J. Yukawa, N. Uechi, S. Sato \& T. Ganaha, 2004.
Gall-inducing species of the family Cecidomyiidae (Diptera) recorded from the Korean Peninsula and surrounding islands, in comparison with the gall-midge fauna of Japan. Esakia, (44): 57-66.

Saitô, K., 1932. [Studies of insect galls in Korea]. Bull. Sci. Res. Alumni Assoc. Morioka Coll. Agr. Forest., (7): 93-107. (In Japanese.)

Sato, S., T. Ganaha, J. Yukawa, Y. Liu, J-C. Paik, N. Uechi \& M. Mishima, 2009. A new species of the genus Rhopalomyia (Diptera: Cecidomyiidae) inducing large galls on wild and cultivated Chrysanthemum (Asteraceae) in China and on Jeju Island, Korea. Appl. Entomol. Zool., 44: 61-72.

Sato, S. \& J. Yukawa, 2006. Resurrection of Rabdophaga salicivora Shinji, a Japanese gall midge formerly misidentified as a North American species, Rabdophaga rigidae (Osten Sacken), (Diptera: Cecidomyiidae), with observations on the phylogenetic relationships of its populations in Japan and the Russian Far East. Entomol. Sci., 9: 423-434.

Yukawa, J. \& H. Masuda, 1996. Insect and Mite Galls of Japan in Colors. 826 pp., Zenkoku Nôson Kyôiku Kyôkai, Tokyo. (In Japanese with English explanations for color plates.)

Yukawa, J. \& K. Tsuda, 1987. A new gall midge (Diptera: Cecidomyiidae) causing conical leaf galls on Celtis (Ulmaceae) in Japan. Kontyû, 55: 123-131.

Yukawa, J., S. Sato, K. M. Harris, M. Tokuda, M. Sasaki, A. Arakawa, K. Nakada \& N. Sawamura, 2009. A new species of Resseliella (Diptera: Cecidomyiidae), infesting Japanese pear, Pyrus pyrifolia (Rosaceae). Appl. Entomol. Zool., 44: 655-666.

Yukawa, J., H. Ikenaga, S. Sato, M. Tokuda, T. GanahaKikumura, N. Uechi, K. Matsuo, M. Mishima, G. H. Tung, J. C. Paik, B. Q. Ren \& X. O. Don, 2012. Description and ecological traits of a new species of Pitydiplosis (Diptera: Cecidomyiidae) that induces leaf galls on Pueraria (Fabaceae) in East Asia, with a possible diversification scenario of intraspecific groups. Entomol. Sci., 15: 81-98. 